\title{
Induction and Growth Kinetics Callus of Tomato (Solanum lycopersicum)
}

\author{
Arkan Setiaji ${ }^{1}$, RR Rifka Annisa ${ }^{1}$, Sismindari $^{2}$, Rumiyati Rumiyati $^{2}$, Endang Semiarti ${ }^{3 *}$ \\ ${ }^{1}$ Undergraduate Program of Biology, Faculty of Biology, Universitas Gadjah, Mada Indonesia \\ ${ }^{2}$ Department of Pharmaceutical Chemistry, Faculty of Pharmacy, Universitas Gadjah, Mada Indonesia \\ ${ }^{3}$ Department of Tropical Biology, Faculty of Biology, Universitas Gadjah, Mada Indonesia \\ *Email: endsemi@ugm.ac.id
}

Submitted: 31 October 2019. Revised: 11 January 2020. Accepted: 20 March 2020

\begin{abstract}
Plant callus extracts are potential to be developed as ingredient in skincare products. Tomato callus is supposed to contain protein-derivatives and or other components such as secondary metabolites that play a role in skin regeneration. Therefore the production of calli is important to be studied for callus sustainable supply. This research aims to obtain optimum medium for callus induction and to analyze tomato callus development anatomically. In vitro culture response was assessed in tomato plant (Solanum lycopersicum L. 'Permata') for optimum callus induction. Seeds were grown on 1/4 MS medium for 10-15 days. Hypocotyl was excised and cultured on MS medium $+2 \mathrm{mg} / 1$ 2,4-D for 15 days as the explants for callus induction. Callus was transferred to MS medium with 8 variations of PGRs including the combination of BAP + NAA, and 2,4-D. Both fresh and dry weight was measured every 5 days over 60 days to establish the growth kinetics and growth efficiency of callus. Anatomic characters of calli were examined through paraffin-embedded method. The result showed of MS medium supplemented with $2.0 \mathrm{mg} / 1 \mathrm{NAA}$ and $0.2 \mathrm{mg} / \mathrm{l} \mathrm{BAP}$ is optimum for tomato callus induction, based on highest number of the absolute growth rate on fresh weight (73.77\% per day), dry weight (3.84\% per day), and callus initiation time (5.56 days) achieved by the medium. Cells in the ground tissue of tomato hypocotyl are competent to be dedifferentiated into a callus. This research results were expected to find out suitable methods for tomato callus production in preparation for skincare uses.
\end{abstract}

Key words: callus; growth efficiency; in vitro medium; tomato

How to Cite: Setiaji, A., Annisa, R. R., Rumiyati, R., \& Semiarti, E. (2020). Induction and Growth Kinetics Callus of Tomato (Solanum lycopersicum). Biosaintifika: Journal of Biology \& Biology Education, 12 (1), 35-41

DOI: http://dx.doi.org/10.15294/biosaintifika.v12i1.21704

\section{INTRODUCTION}

Secondary plant products have been considered as one of the main sources of pharmaceuticals, flavor, agrochemicals, nutrition, and industrial biochemical. Production of plant secondary metabolites including how their biosynthesis and how to improve the products by in vitro culture technologies have been extensively studied since the 1960s (Bourgaud et al., 2001). Plant cell cultures have been widely known as technique for accommodating the production of largescale high-value metabolites by cost-effective using a bioreactor (Georgiev et al., 2009).

Callus formation from the primary explant has already known as an effective culture method. Callus cultures can be sub-cultured to another medium to form organogenesis, embryogenesis, cells suspension in batch culture, or to maintain as callus (Cardoza, 2016). Callus is a wound covering tissue, proliferated cells from a cut region of explant, caused by an infection of pathogens, or induced by plant growth regulators (Smith, 2012; Ikeuchi et al., 2013). Callus is generally formed to be friable, hard and compact, vacuolated cells that are highly differentiated, contain regions of small meristematic cell clusters but unorganized (Efferth, 2018).
Tito et al. (2011) reported that tomato cell culture extract contains antioxidant compounds such as flavonoids, hydroxycinamic acid, glycoalkaloid, phenolic acid, and terpenoids. This extract also contains phytochelatins for the protection of skin cells towards heavy metal toxicity. Previous studies have found that tomato callus extract has cytoprotective activity in preventing $\mathrm{H}_{2} \mathrm{O}_{2}$-induced on Vero and Human Dermal Fibroblast adult (HDFa) cells and inhibiting cell death (Hana, 2016; Prastowo, 2017; Utama, 2018; Dewi, 2018; Rumiyati et al., 2018). This extract is rich in polyphenols and flavonoids with low antioxidant activity, or much lower than tomato fruits (Hana, 2016). Tomato callus is also predicted to contain proteinderivatives that play a role in cell regeneration (Rumiyati et al., 2018).

The establishment of an efficient tomato callus production is important due to its development for nutraceutical products or other purposes. General concessions that stated if cytokinin and auxin are added in intermediate ratio concentrations into the basal medium will induce callus, as described by Skoog and Miller (1957) has changed a lot (Ikeuchi et al., 2013). The type and optimal concentration of PGRs are related to the variety of tomatoes and the 
source of the explants used. Studies showed a diverse result, either using 2,4-Dichlorophenoxyacetic acid (2,4-D), 1-Naphthaleneacetic acid (NAA), and 6Benzylaminopurine (BA) as a single dose, or as a combination with a higher or lower BA, has the same potential to optimize tomato callus induction (Osman et al., 2010; Jan et al., 2015; Shah et al., 2015).

This research aims to obtain optimum medium for callus induction and to observe tomato callus development anatomically. Therefore, the concentration of PGRs needs to be optimized against tomato (Solanum lycopersicum L.) 'Permata', superior local cultivars that are most responsive to callus induction (Rumiyati et al., 2017). In the future, this tomato callus culture method is possible to be used for the large production and to standardize its active ingredients in callus production.

\section{METHODS}

\section{Plant materials}

Seeds of cultivar of tomato 'Permata' were purchased from East-West Seed Indonesia Ltd. The seeds were sterilized in $30 \%$ solution of bleach containing $5.5 \%(\mathrm{w} / \mathrm{v})$ of sodium hypochlorite for 5 minutes and continued with rinsing in sterile distilled water (3 times for 1 minute). Subsequently, they were surface sterilization in $70 \%(\mathrm{v} / \mathrm{v})$ ethanol for 1 minute. Next, they were washed in sterile distilled water (3 times for 1 minute). The surface-sterilized seeds were inoculated on $1 / 4$ strength MS medium to germinate and incubated for 10 days.

\section{Callus induction}

Ten days old in vitro grown seedlings were used as the source of explants. Hypocotyl was excised about 1 $\mathrm{cm}$ and planted on basal Murashige \& Skoog (1962) (MS) medium (3\% sucrose, $0.65 \%$ agar) supplemented with 2 mg. $1^{-1} 2,4-D$ for 15 days. Grown callus was sub-cultured on a fresh medium containing 8 variations of PGRs concentrations (Table 1.) for the next 60 days. On the other hand, hypocotyls were planted in 8 variations of PGRs concentrations (Table 1.) to observe the respond and the formations of callus. For all media used, the $\mathrm{pH}$ of the medium was adjusted to 6.0 before sterilized in an autoclave $\left(121^{\circ} \mathrm{C}, 15 \mathrm{psi}\right.$, 15 minutes). Cultures were kept in an incubation room at $24 \pm 2{ }^{\circ} \mathrm{C}$ under continuous light conditions (3,000 lux, approx.).

\section{Histological examination of callogenesis}

The callus at different ages was used, i.e. $1^{\text {st }}, 6^{\text {th }}$, $12^{\text {th }}, 16^{\text {th }}, 18^{\text {th }}$, and $24^{\text {th }}$-day culture. The samples were fixed in a standard fixative Formalin-Aceto-Alcohol (FAA) solution. Fixed materials were dehydrated serially using xylol and alcohol, which take out the water in the samples. Paraffin wax was used for infiltration and embedding. Uniformly thin sections of 10 $\mu \mathrm{m}$ thickness were cut using a rotary microtome. Safranin $1 \%$ stain was used to staining cell walls.

Table 1. Variation in concentration and type of PGRs for callus propagation (mg. $\mathrm{l}^{-1}$ )

\begin{tabular}{llll}
\hline Treatments & BA & NAA & $2,4-D$ \\
\hline CIM0 & - & - & - \\
CIM1 & 0.5 & 0.5 & - \\
CIM2 & 2.0 & 2.0 & - \\
CIM3 & 0.2 & 2.0 & - \\
CIM4 & 2.0 & 0.2 & - \\
CIM5 & - & - & 1.0 \\
CIM6 & - & - & 1.5 \\
CIM7 & - & - & 2.0 \\
CIM8 & - & - & 2.5 \\
\hline
\end{tabular}

$\mathrm{CIM}=$ callus induction medium

\section{Data Analysis}

Both fresh and dry weight is measured every 5 days in 60 days, the data were plotted to establish growth curve. Growth index (GI), absolute growth rate (AGR), specific growth rate (SGR), and doubling time (DT) formulas are used to measure the growth efficiency between treatments (Loyola-Vargas \& Vázquez-Flota, 2006). Data were analyzed in ANOVA and comparisons between treatments were made with Duncan's multiple range test at $\alpha=0.05$. Data presented as average \pm standard error (SE).

\section{RESULTS AND DISCUSSION}

\section{Callus Initiation}

Swelling explants were observed within 5-8 days in all media, while the formation of callus was initiated within 5-13 days. In this experiment, hypocotyls explants were used because some previous studies reported that these explants were superior (produced more callus) compared to cotyledon, which is often used as an explant for plant regeneration in different tomato cultivars (Osman et al., 2010; Yasmeen, 2009; Ali et al., 2012; Gerzberg et al., 2016).

The shortest callus induction time observed in CIM3 while the longest was in CIM6. Callus was directly grown on both cutting sites of hypocotyl, where those two cutting areas become blackish. It should be noted that this observation is based on visible signs on the explant surface, it is possible that the callus may be developed earlier in the parenchymal tissue that was not observed macroscopically. Callus induced by a combination BA and NAA produced green callus with compact texture (Figure 1A), while 2,4-D presented a pale yellow color and produce friable calli (Figure 1B). 

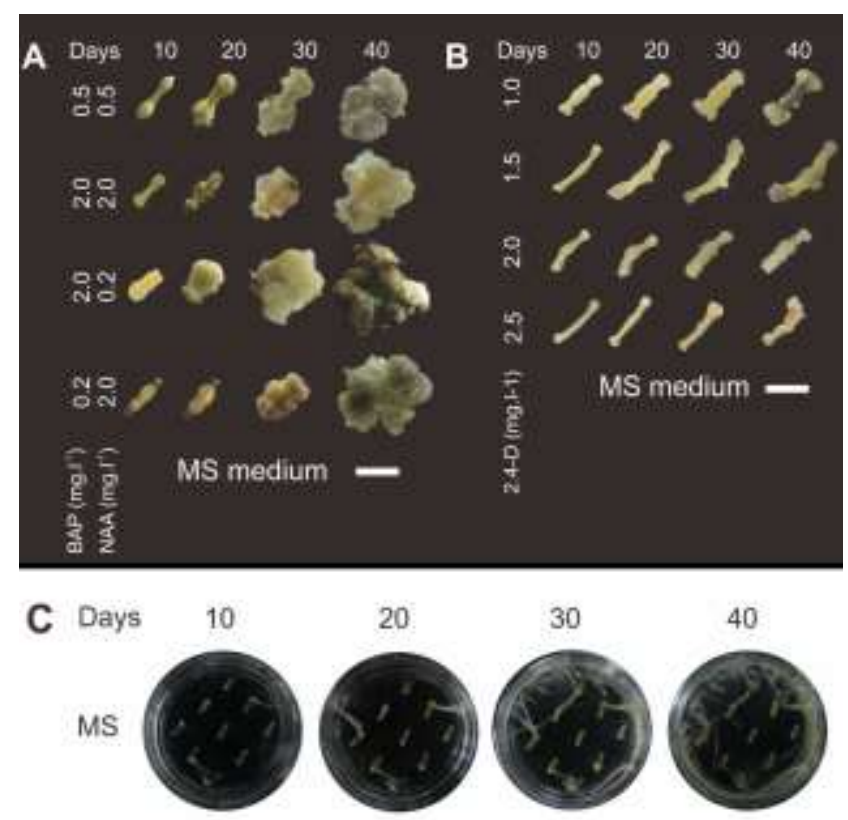

Figure 1. Responses of hypocotyl explants with various PGRs concentrations on MS medium. (A) MS + combination of BA and NAA; (B) MS + 2,4-D; (C) MS0. Callus growth data were taken at 10, 20, 30, and 40 days after explant plantation on medium. Scale bars $=1 \mathrm{~cm}$

No callus formation observed on hormone-free medium, but there is a massive root formation that occurred (Figure 1C). After $10^{\text {th }}$ days, root length could reach more than $2 \mathrm{~cm}$. Root formation in tomatoes does not demand any exogenous PGRs because of the endogenous auxins content was relatively high (Rashid \& Bal, 2010; Bahurupe et al., 2013; Jehan \& Hassanein, 2013). Nevertheless, the majority of the rooting cases promotes by the high ratio of auxin-tocytokinin or auxin alone (Skoog \& Miller, 1957).

2,4-D is known to induced callus formation by mimicking the action of the auxin and revert the cells back into the meristematic state, called dedifferentiation, and begin to proliferate (George et al., 2008). For callus induction, 2,4-D commonly used as a single dose, while the other auxin such as NAA has to be combined with cytokinin to get a good result. A combination of cytokinin and auxin, i.e BA and NAA or IAA, have been widely used to generate callus formation, although the mechanism of this combination to promotes callus formation is still unclear. Both cytokines and auxins as a single-use could work synergistically as a signal to activate genes responsible for callus formation (Ikeuchi et al., 2013). 2,4-D usually produced friable callus for cell suspension culture, while auxin-cytokinin produced higher callus biomass with compact texture for explant organogenesis. The in vitro morphogenetic responses of plant callus induction is affected by different components of the culture media and plant growth regulators $(\mathrm{Gu}-$ bis et al., 2004).

\section{Histological Analysis}

Callus growth occurs at the back of the explant cutting area which may be due to cells in the former truncation experiencing death, or in some other cases appearing at both ends of the explant (Figure 2B). Samples collected at 12 days showed the emergence of adventitious root primordia at parts close to both ends of explants. This is because the distribution of the absorbed hormones may differ between regions near the injury that first form the callus compared to the middle of the explant. The emergence of adventitious root primordia (Figure 2C) in early callus development in CIM3 may be due to the concentration of NAA which is 10 times higher than BAP, and this is in accordance with the statement of Skoog and Miller (1957) where high concentrations of auxin cause root emergence. But this organogenesis stops when cells turn into callus.

It is well known that callus cells are thought to be a differentiation from parenchymal cells (Zhu, 2017), but studies on Arabidopsis, buds or roots incubated in a medium containing a combination of cytokinins and auxins form more callus and begin in deeper tissue, namely pericycle xilem-pole (Atta et al., 2009). Pericycle xilem-pole cells are cells in the perisicle adjacent to the protoxylem-pole of a vascular bundle. Perisicle cells adjacent to other xylem cells in vascular bundles are not considered pericycle xilem-pole cells. Pericycle xilem-pole cells can maintain some meristematic activity, including as a place for lateral root initiation (Parizot et al. 2008). In this study, due to the development of the pericycle xilem-pole, the spiral tracheids spread because of the pressure of cell division along with callus development (Figure 2E). Parenchymis cells in explants also develop during callus formation (Figure 2E,F).

Hypocotyl-derived callus life cycle builds sigmoid curves, contained lag, exponential, linear, progressive deceleration and stationary phases (Figure 3). Growth curves were plot based on fresh and dry weights. Plant cells enter the lag phase (adaptive period) start from 5-15 days, it was faster than that by using 2,4-D supplemented medium. Cell diameter and density decreased, while intensive cell division occurred at the end of the phase (Mendonça et al., 2012). A significant increment growth (exponential phase), as the period of maximum cellular division and cell growth rate, occurred between 15-30 days on BA-NAA supplemented medium and 5-10 days on 2,4-D supplemented medium. The cells subsequently enter a phase of constant growth (linear phase) during about 15 days with BA-NAA supplemented medium and only 5 days on the 2,4-D medium. In this period the cellu- 
lar division was decreases, density and volume of the cells were constant (Mendonça et al., 2012). The primary metabolites also produced continuously during the exponential and linear phases of growth (Prins et al., 2010).

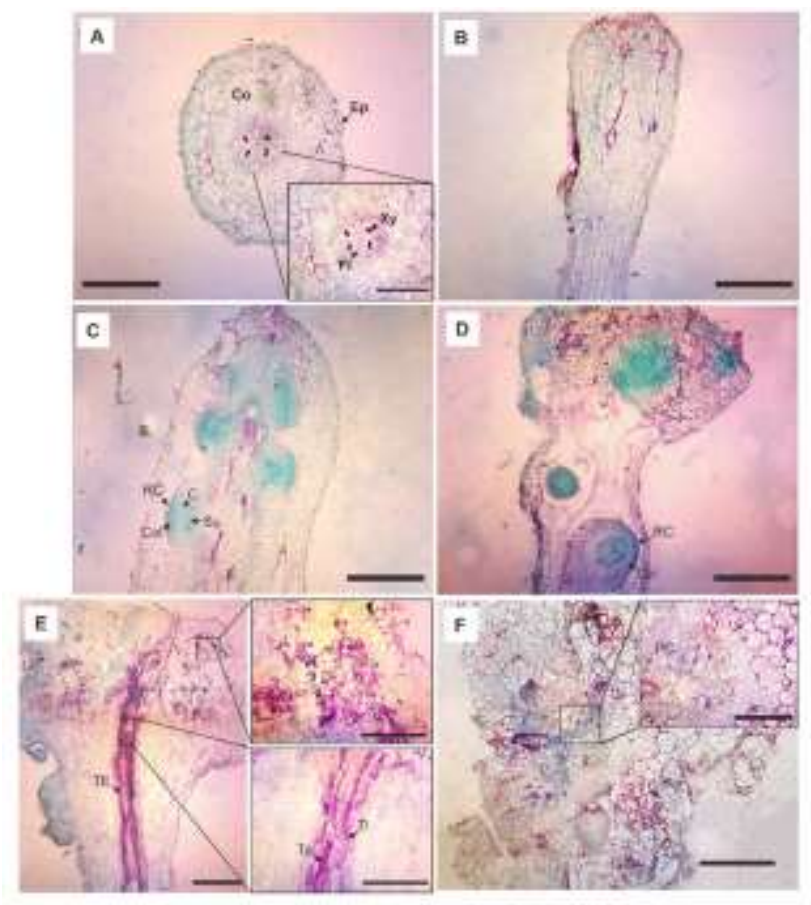

Figure 2. Histological observation of tomato callus development on CIM3. (A) Hypocotyl as explants; (B) Swelling at the hypocotyl cut end, age 6 days after planting; (C) Adventitious roots appear on the $12^{\text {th }}$ day; (D) On the $16^{\text {th }}$ day, the tip of the explant is increasingly swollen and the lateral root experiences structural thickening; (E) Day 18, Callus cells pressurize vascular tissue; (F) Day 24, callus cells dominate and show an amorphous structure and disorganized distribution.

\section{Growth Curve}

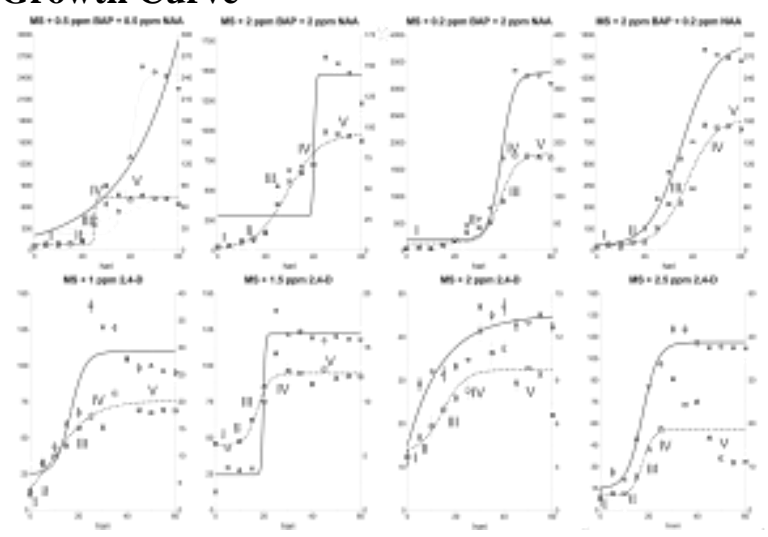

Figure 2. Growth curve indicating the growth change of callus. I - lag phase, II - exponential phase, III linear growth phase, IV - progressive deceleration and $\mathrm{V}-$ stationary phase. $\mathrm{FW}=$ fresh weight, $\mathrm{DW}=$ dry weight.
The next transient phase is short, with each treatment average during only 5-10 days. Continued consumption of the limiting nutrient causes a progressive decrease in cell growth rate (progressive deceleration phase). If there is no nutrient renewal, the cells will enter the stationary phase which will continue to the cell death phase. In this phase, the biomass is still increasing, but the rate of cellular division is reduced and the cell number is remain standstill (Moscatiello et al., 2013). It caused by depletion of nutrients and reduction of the $\mathrm{O}_{2}$ amounts inside the cells (Smith, 2012). During this phase, secondary metabolites compounds, the end products of primary metabolites increase correlating with cell death and may become toxic (phenols containing) to the cells (Smetanska, 2008).

\section{Growth Efficiency \\ Growth index and doubling time}

Both fresh and dry weight are measurements of absolute biomass at the time of sampling, it can be hourly, per day, or per 5 days as in this study. No standard references to actual growth efficiency are considered. The growth index is calculated as the ratio of the initial and accumulated biomass (LoyolaVargas \& Vázquez-Flota, 2006). The highest growth indexes for callus fresh weight obtained on CIM3 was $39.10 \pm 15.64$ and minimum GI was observed on CIM7 (2.79 \pm 0.43$)$ (Figure 4A).

Doubling time (DT) is the time required for a quantity of the biomass of callus to double (Hitchcock et al., 2017). DT can be calculated using a growth rate trend, natural logarithmic from 2 per specific growth rate. The existence of a mean tomato callus DT in cultures does not imply that each cell in the proliferating callus, divides with the same constant DT. In callus mass, certain cell groups may grow faster than others. Based on Figure 4B, doubling time of FW on CIM2 is the highest, $5.42 \pm 0.62$ days, while in FW, i.e. on CIM1 (3.52 \pm 0.12 days).

\section{Growth rate}

The absolute growth rate is the simplest index of growth analysis, a rate of the change either increment or decrease in size per unit time (Hunt, 2012). Medium with combinations of BA + NAA has AGR that is much higher than the medium with 2,4-D. Highest value in FW and DW are on CIM3, i.e. $73.77 \pm 2.25$ mg.day ${ }^{-1}$ and $3.84 \pm 0.05 \mathrm{mg}^{-d_{a y}{ }^{-1}}$ (Figure $5 \mathrm{~A}, \mathrm{~B}$ ), respectively. The rate of specific growth is measured when the population density reaches one-half of the carrying capacity and during this period, the increase in the cell population fits a straight-line equation (Pommerening and Muszta, 2016). In medium supplemented with 2,4-D, cell growth during the exponential-linear phase occurs rapidly, clearly shown 
through the dry weight. In SGR parameter, the highest value of FW on CIM6 is $12.92 \pm 2.77$ mg.day $^{-1}$ (Figure 5C) while on DW is on CIM1 is $19.75 \pm 0.68$ mg.day ${ }^{-1}$ (Figure 5D).

\section{A}

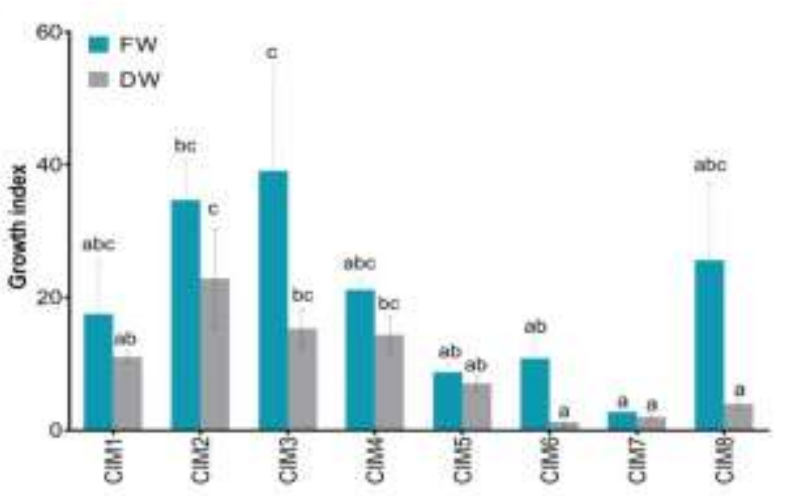

B

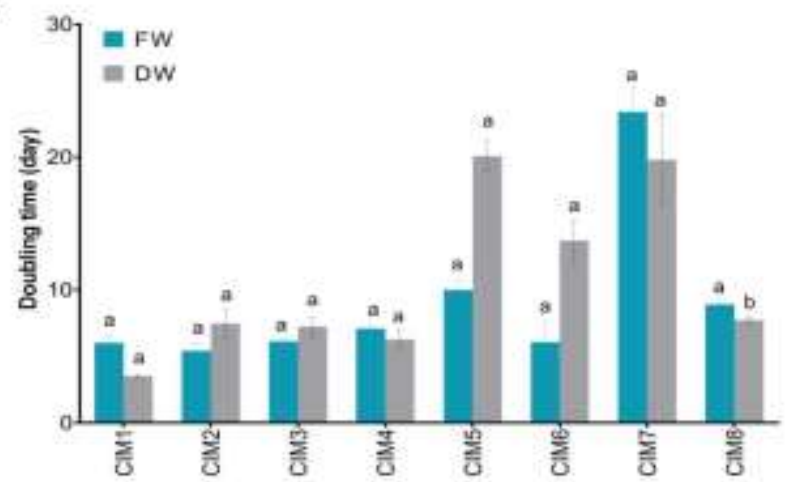

Figure 4. Growth index (A) and doubling time (B) on tomato callus. $\mathrm{FW}=$ fresh weight, $\mathrm{DW}=$ dry weight
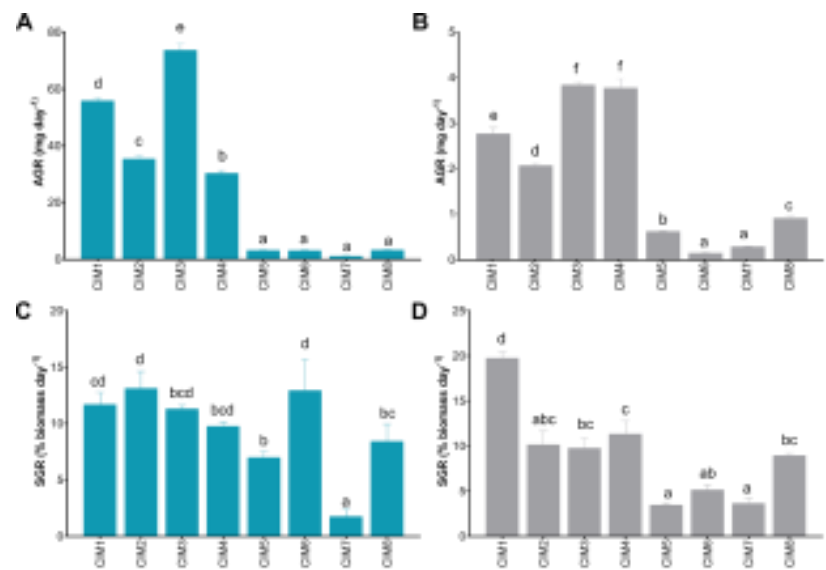

Figure 5. Absolute growth rate (AGR) and specific growth rate (SGR) on tomato callus. (A) AGR on fresh weight; (B) AGR on dry weight; (C) SGR on fresh weight; (D) and SGR on the dry weight

Based on the growth efficiency parameters, medium supplemented with $2.0 \mathrm{mg} . \mathrm{l}^{-1} \mathrm{NAA}+0.2 \mathrm{mg} . \mathrm{l}^{-1}$ BA shows the highest value at induction time, growth index of fresh weight, absolute growth rate of fresh and dry weight, and other values that are not significantly different from the optimum treatment at each parameter on tomato callus. Taking measurements on the dry weight of the callus by simply comparing the highest value is not the right thing. Each cell culture has a life cycle with certain phases that may be faster or slower than other phases, and this determines when the cell is harvested, for example, primary metabolites that should be harvested during the growth phase or secondary metabolites that are harvested when cells become stressed. Matters relating to growth efficiency are important and a correlation between biomass and the time of its achievement should be noted.

From this research it can be seen that hypocotyl cells from tomato 'Permata'plants are potential explants that can be used to produce callus on MS media with the addition of $2.0 \mathrm{mg} .1-1 \mathrm{NAA}+0.2 \mathrm{mg} .1-1 \mathrm{BA}$. The optimal laboratory scale induction and production of tomato callus can be used as a basis for industrial scale tomato callus production in order to extract secondary metabolites from the tomato callus for the manufacture of anti-aging skin care creams.

In the future it is also necessary to confirm the secondary metabolite content in each growth phase of callus to ascertain what phase of the tomato callus should be harvested.

\section{CONCLUSION}

This study has revealed that MS medium supplemented with a combination of $2.0 \mathrm{mg} \cdot \mathrm{l}^{-1} \mathrm{NAA}$ and 0.2 mg. $\mathrm{l}^{-1} \mathrm{BA}$ is the optimum medium for callus induction of Tomato (Solanum lycopersicum 'Permata') using hypocotyl as explants. Cells in the ground tissue of tomato hypocotyl are competent to be used for producing callus.

\section{ACKNOWLEDGMENT}

The research was supported in part by "Dana Masyarakat Mengikat" grant "Kolaborasi Dosen dan Mahasiswa" Faculty of Biology, Universitas Gadjah Mada (No. UGM/BI/1672/M/02/05) given to ES as PI, and in part was supported by PTUPT Research Grant from the Ministry of Higher Education and Technology in the scheme Decentralization UGM No. 2718/ UN1.DITLIT / DIT-LIT/ LT/ 2019 awarded to $\mathrm{S}, \mathrm{R}$ and $\mathrm{ES}$.

\section{REFERENCES}

Ali, A., Yossef, T., \& El-Banna, A. (2012). Cytokinin-cytokinin interaction ameliorates the callus induction and plant regeneration of tomato (Solanum lycopersicum Mill.). Acta Agronomica Hungarica, 60(1), 47-55.

Atta, R., Laurens, L., Boucheron Dubuisson, E., Guivarc'h, A., Carnero, E., Giraudat Pautot, V., Rech, P., \& Chriqui, D. (2009). Pluripotency of 
Arabidopsis xylem pericycle underlies shoot regeneration from root and hypocotyl explants grown in vitro. The Plant Journal, 57(4), 626-644.

Bahurupe, J. V., Patil, S. C., Pawar, B. D., Chimote, V. P., \& Kale, A. A. (2013). Callus induction and plantlet regeneration in tomato (Solanum lycopersicum L.). Journal of Cell \& Tissue Research, 13(2), 3765-3768.

Bourgaud, F., Gravot, A., Milesi, S., \& Gontier, E. (2001). Production of plant secondary metabolites: a historical perspective. Plant science, 161(5), 839-851.

Cardoza, V. (2016). Tissue Culture: the manipulation of plant development. In C. N. Stewart Jr (Eds.), Plant Biotechnology and Genetics: principles, techniques, and applications (pp. 113-132). New Jersey, NJ: John Wiley \& Sons.

Dewi, D.A. (2018). The death inhibition test of ethanol extract and tomato plant stem water (Solanum lycopersicum L.) on human dermal fibroblast adult ( $\mathrm{HDFa}$ 's cell line induced by hydrogen peroxide $\left(\mathrm{H}_{2} \mathrm{O}_{2}\right)$ (Unpublised undergraduate thesis). Universitas Gadjah Mada, Yogyakarta, Indonesia.

Efferth, T. (2018). Biotechnology applications of plant callus cultures. Engineering, 5(1), 51-59.

Georgiev, M. I., Weber, J., \& Maciuk, A. (2009). Bioprocessing of plant cell cultures for mass production of targeted compounds. Applied microbiology and biotechnology, 83(5), 809-823.

Gerszberg, A., Hnatuszko-Konka, K., Kowalczyk, T., \& Kononowicz, A. K. (2016). Efficient in vitro callus induction and plant regeneration protocol for different Polish tomato cultivars. Notulae Botanicae Horti Agrobotanici Cluj-Napoca, 44(2), 452-458.

Gubis, J., Lajchová, Z., Faragó, J., \& Jureková, Z. (2004). Effect of growth regulators on shoot induction and plant regeneration in tomato ( $\mathrm{Lyco}$ persicon esculentum Mill.). Biologia, 59(3), 405408.

Hana, C.A. (2016). Analysis of the dominant compound content and proteins content in tomato plants (Solanum lycopersicum L.) stem cells and antioxidant activity test (Unpublished undergraduate thesis). Universitas Gadjah Mada, Yogyakarta, Indonesia.

Hitchcock, A., Hunter, C. N., \& Sener, M. (2017). Determination of cell doubling times from the return-on-investment time of photosynthetic vesicles based on atomic detail structural models. The Journal of Physical Chemistry B, 121(15), 37873797.

Ikeuchi, M., Sugimoto, K., \& Iwase, A. (2013). Plant callus: mechanisms of induction and repression. The Plant Cell, 25(9), 3159-3173.
Jan, S. A., Shah, S. H., Ali, S., \& Ali, G. M. (2015). The effect of plant growth regulators on callus induction and somatic embryogenesis of hybrid tomato. Pakistan Journal of Botany, 47(5), 16711677.

Jehan, S., \& Hassanein, A. M. (2013). Hormonal requirements trigger different organogenic pathways on tomato nodal explants. American Journal of Plant Sciences, 4(11), 2118-2125.

Loyola-Vargas, V. M., \& Vázquez-Flota, F. (2006). An introduction to plant cell culture. In VM. Loyola-Vargas \& F. Vázquez-Flota (Eds.), Plant cell culture protocols (pp. 3-8). New Jersey, NJ: Humana Press.

Mendonça, E. G., Paiva, L. V., Stein, V. C., Pires, M. F., Santos, B. R., \& Pereira, F. J. (2012). Growth curve and development of the internal calli structure of Eucalyptus camaldulensis Dehn. Brazilian Archives of Biology and Technology, 55(6), 887896.

Moscatiello, R., Baldan, B., \& Navazio, L. (2013). Plant cell suspension cultures. In Maathuis F. (Eds.), Plant Mineral Nutrients (pp. 77-93). New Jersey, NJ: Humana Press.

Murashige, T., \& Skoog, F. (1962). A revised medium for rapid growth and bio assays with tobacco tissue cultures. Physiologia plantarum, 15(3), 473497.

Osman, M. G., Elhadi, E. A., \& Khalafalla, M. M. (2010). Callus formation and organogenesis of tomato (Lycopersicon esculentum Mill, CV Omdurman) induced by thidiazuron. African Journal of Biotechnology, 9(28), 4407-4413.

Osman, N. I., Awal, A., Sidik, N. J., \& Abdullah, S. (2013). Callus induction and somatic embryogenesis from leaf and nodal explants of Lycium barbarum L.(Goji). Biotechnology, 12(1), 36-45.

Parizot, B., Laplaze, L., Ricaud, L., BoucheronDubuisson, E., Bayle, V., Bonke, M., De Smet, I., Poethig, S. R., Helariutta, Y., Haseloff, J., \& Chriqui, D. (2008). Diarch symmetry of the vascular bundle in Arabidopsis root encompasses the pericycle and is reflected in distich lateral root initiation. Plant Physiology, 146(1), 140-148.

Pommerening, A., \& Muszta, A. (2016). Relative plant growth revisited: Towards a mathematical standardisation of separate approaches. Ecological modelling, 320, 383-392.

Prastowo, D. (2017). Cytoprotective effect in vitro test of tomato (Lycopersicon esculentum Mill.) stem cell extract and reduction power test by FRAP (ferric reducing antioxidant power) method (Unpublised undergraduate thesis). Universitas Gadjah Mada, Yogyakarta, Indonesia.

Prins, C. L., Vieira, I. J., \& Freitas, S. P. (2010). Growth regulators and essential oil produc- 
tion. Brazilian Journal of Plant Physiology, 22(2), 91-102.

Rashid, R., \& Bal, S. S. (2010). Effect of hormones on direct shoot regeneration in hypocotyl explants of tomato. Notulae Scientia Biologicae, 2(1), 7073.

Rumiyati, S., Nurrochmad, A., Semiarti, E., Widyarini, S., Prastiandari, D., Utama, A. D., \& Dewi, D. A. (2019). Cytoprotective activity of tomato and carrot callus on human dermal fibroblast adult (HDFa). In T. R. Nuringtyas, L. Hidayati \& M. Rafieiy (Eds.), $1^{\text {st }}$ International Conference on Bioinformatics, Biotechnology, and Biomedical Engineering (pp. 1-8). AIP Publishing. Retrieved from https://aip.scitation.org/doi/pdf/10.1063/1.

Rumiyati, S., Semiarti, E., Milasari, A. F., Sari, D. K., Fitriana, N., \& Galuh, S. (2017). Callus induction from various organs of dragon fruit, apple and tomato on some mediums. Pakistan Journal of Biological Sciences, 5, 244-252.

Shah, S. H., Ali, S., Jan, S. A., Din, J., \& Ali, G. M. (2015). Callus induction, in vitro shoot regeneration and hairy root formation by the assessment of various plant growth regulators in tomato (Solanum lycopersicum Mill.). Journal of Animal and Plant Sciences, 25(2), 528-538.

Skoog, F., \& Miller, C. (1957). Chemical regulation of growth and organ formation in plant tissues cultured in vitro. Symp. Soc. Exp. Biol., 11, 118-130.
Smetanska, I. (2008). Production of secondary metabolites using plant cell cultures. In U. Stahl, U. E. Donalies, E. Nevoigt. (Eds.), Food Biotechnology: advances in biochemical engineering/biotechnology (pp. 187-228). Berlin: Springer. Smith, R. H. (2012). Plant tissue culture: techniques and experiments. New York, NY: Academic Press.

Tito, A., Carola, A., Bimonte, M., Barbulova, A., Arciello, S., de Laurentiis, F., Monoli, I., Hill, J., Gibertoni, S., Colucci, G., \& Apone, F. (2011). A tomato stem cell extract, containing antioxidant compounds and metal chelating factors, protects skin cells from heavy metal induced damages. International Journal of Cosmetic Science, 33(6), 543-552.

Utama, A.D. (2018). Activity cytoprotective test of ethanol extract and tomato (Solanum lycopersicum L.) plant stem water through cell cycle profiles modulation on human dermal fibroblast adult ( $\mathrm{HDFa}$ ) exposed by hydrogen peroxide $\left(\mathrm{H}_{2} \mathrm{O}_{2}\right)$ (Unpublished undergraduate thesis). Universitas Gadjah Mada, Yogyakarta, Indonesia.

Yasmeen, A. (2009). An improved protocol for the regeneration and transformation of tomato (cv Rio Grande). Acta physiologiae plantarum, 31(6), 1271.

Zhu, J. (2017). Plant stem cell and its pluripotency. International Journal of Stem Cell Research, 3(1), 1-6. 